\title{
Haven an a Heartless Sea: The Sailors' Tavern in History and ANTHROPOLOGY
}

\section{Michael Seltzer}

Once a fixture on the waterfronts of seaports the world over, taverns providing merchant sailors with lodgings have nearly disappeared today in the wake of technological changes in maritime shipping. Though glimpses of sailors' taverns are scattered in bits and pieces throughout works of maritime history and diverse accounts of seafaring life, our knowledge of them is far from complete. In an attempt to furnish a fuller picture of tavern life, this paper opens with an overview of tavern life as described in popular histories, works of fiction, biographies, autobiographies, missionary tracts, and social historical writings. It concludes with an ethnographic framing of tavern on the basis of data earlier collected by this writer as a participant in and observer of tavern and shipboard life (Seltzer 1971, 1973). Then as now, attending to lives of sailors ashore also requires attending to the special nature of their working lives at sea.

In the first place, shipboard work is unique in its domination of the lives of sailors. While most workers on land have evening and weekend breaks away from their workplaces, work at sea flows in an unbroken stream. The basic tasks of seafaring--sailing and maintaining vessels as well as loading and unloading cargoes-are constant. Watch after watch, day by day, week after week, and month after month, sailors carry out these tasks while eating, sleeping and living aboard worksites in motion. 
In so doing, little differentiates today's work situations on tankers, roll-on/roll-off cargo vessels and bulk carriers from those of English merchant ships of the seventeenth century described by the historian Peter Earle: "Week after week, the work went on, punctuated only by the comparative rest of Sundays when duties were usually confined to washing the ship" (1988:81). Similarly, deck work on modern vessels is much like that of the 1830 s described by Richard Henry Dana:

The discipline of the ship requires every man to be a work upon something when he is on deck....you will never see a man, on board a well-ordered vessel, standing idle on deck, sitting down, or learning over the side. It is the officer's duty to keep every one at work, even if there is nothing to do (1948: 20).

Work at sea also dominates other spheres of the sailor's life. As a workplace the ship has much in common with prisons, mental hospitals and other institutions confining and isolating their inmates. Sailors commonly refer to their shipboard stays as "voluntary prison time" and the social and psychological deprivations shared by prisoners, psychiatric patients and seafarers have been noted by a number of behavioral and social scientists (e.g., Aubert 1966; Aubert and Arner 1958/59; Fricke 1973, 1974; Goffman 1961; Moreby 1975; Nolan 1973; Zurcher 1965)

Seafarers subject to the demands and constraints of the ship long have integrated spells of non-work ashore in their occupational careers. Typically they contract to work on vessels for fixed periods or until asking to be discharged from their duties. Consequently, their working lives are punctuated by recurrent cycles of signing on and paying off ships. It has been estimated that a sailor serves aboard 40 to 50 ships during the course of an average working career. ${ }^{1}$ Other estimates of the time spent onboard by the sailor vary from 2 ships each year to shorter stays of 2 to 4 months at a time (Fricke 1973). 
The sailor's life thus swings pendulum-like between spells at sea and stays on land. Since opportunities for shipboard spending are limited, seafarers tend to accumulate considerable sums of money while working at sea. Indeed, many sailors view these stays as periods of effortless savings. Given the deprivations of life and work at sea, newly discharged sailors may use their stores of cash to obtain what has been denied them aboard the ship. Like prisoners and patients released from other institutional settings where all spheres of life are lived by groups in closed and controlled settings, newly discharged sailors face problems of two basic sorts: material and psychological. Their main material problem is to find a place to live ashore. Psychological problems, on the other hand, are more diffuse since many involve fears and anxieties about moving from a small, highly predictable, tightly structured and disciplined milieu to an immense, loosely structured and highly unpredictable environment.

Cataloguing some of the difficulties of this transition, one writer described newly discharged sailors as persons who:

after a long absence...found themselves in a strange world. They were unaccustomed to terra firma, they uttered a strange argot, they were simpletons out of their element [and] ... seemed to have no family background or homelife. They were like characters in modern novels, isolated individuals projected against empty space (Rawson 1958: 99, 65).

As we shall see, the literature contains conflicting appraisals of how sailors' taverns related to these problems. Whether these establishments mitigate or contribute to the psychological problems of sailors ashore is a question inviting different interpretations. But when it comes to material problems of newly discharged sailors, taverns traditionally have provided living spaces for those who can or will not return to their homes and homelands. 


\section{Home Away From Home}

Political exiles long have been prominent among those sailors not returning to their homes and families (e.g., Valtin 1941; Traven 1934; Guthke 1987). Others, particularly seafarers from Third World countries, possess insufficient funds for travelling to their homelands. Some sailors, fearing military conscription and familial obligations, choose not to go home. And owing to seafaring's long history of international and multicultural crews aboard merchant vessels, there always have been homeless sailors. One historian found, for example, one third of all seamen coming to London in the 188 os reported having no homes anywhere in the world (Palmer 1980).

Though their reasons have varied, these sailors have been limited to a few choices of where to spend their lives ashore. Some have lodged in private homes, while others have lived with partners in marital or consensual unions in or near the ports of their discharge. Still others have elected to lodge in facilities established for their welfare by religious and other organizations. And for others, the tavern traditionally has served as a space for shore life.

Still found in a few ports today, these places for centuries were a fixture of waterfront life in ports throughout Europe, the Americas and elsewhere (e.g., Fingard 1982; Hughill 1967; Smith 1924). In Belgium and Holland, one can still find prints and woodcuts depicting seventeenth and eighteenth century streetscapes where sailor lodging houses identifiable by flags of many nations, and their signs "Zeemanskosthuis" are interspersed among the brothels, dancehalls and ships' chandlers pictured along the waterfront. According to one Dutch historian, the housing and credit provided by these establishments were an "absolute necessity” for seamen ashore during this period (Bruijn 1979:331). One seafaring history locates sailor taverns in seaports around the world from the sixteenth century on, but notes their numbers increased greatly throughout the nineteenth century with the 
explosive growth of seaports accompanying the commercial and industrial changes of this period (Hugill 1967:22).

No matter where in the world these establishments were located, they invariably were found in those waterfront districts seafarers called "sailortowns" and "fiddlers' greens." In positioning this territory in the context of seafaring, Eugene O’Neill has a dying seaman in Bound East for Cardiff utter the following:

This sailor life ain't much to cry above leavin', just one ship after another, hard work small pay, and bum grub; and when we git into port, just a drunk endin' up in a fight, and all your money gone ... Never meetin' no nice people; never gettin' outa sailortown, hardly, in any port, travellin' all over the world and never seein' none of it (1951:486).

One sailor-historian recalled that:

Sailortown was of all countries; a Fiddler's Green of pubs, dance-halls, groggeries, and brothels. And, to a sailorman, its main thoroughfare was usually some Shit Street, an effluent maze of alleys found in Sailortowns throughout the world. Such a district would not be so named in port plant, but every sailorman worthy of the name could lead you to at least one in every port of the Seven Seas (Hughill 1967:72).

A more negative characterization of these districts in relation to seafaring life draws from a doctoral dissertation in economics by a former sailor, who writes:

The seaman, when living ashore, is practically a homeless man, and as such, is more or less desocialized. This condition is emphasized by the class of people he meets at the waterfront of many ports. The waterfront in many cities is the last resort of many who are losing their fight for decency. It is, often, the social Gehenna, where a city casts the dregs and wastrels of society.... Runners for boarding house keepers and emissaries of house of evil repute clamber aboard the arriving ships and mingle their cards, cryptic messages and vile pictures with the invitations sent 
out by seamen's missions, laundrymen, tailors and sellers of coupons in trying to get his ear and his money... (Healy 1936:53).

In Billy Budd, Herman Melville provides a similar warning about this area in describing the sailor as:

Habitually living with the elements and knowing little more of the land than as a beach, or rather, that portion of the terraqueous globe providentially set apart for dancehouses, doxies, and tapster, in short what sailors call a "fiddlers' green" (1961:16)

In Redburn, Melville elaborates in describing the residents of these areas as:

land-sharks, land-rats and other vermin which make the helpless mariner their prey. In the shape of landlords, clothiers, barkeepers, crimps and boarding house loungers, the land-sharks devour him limb by limb; while the land-rats and mice nibble at his purse (1928:27).

Though disagreeing about the character of these areas (e.g., Fingard 1982; de Lottinville 1982; Palmer 2000), most observers tend to agree that the tavern providing lodgings for sailors occupied a central niche on the waterfronts of the world (Fingard 1989; Hugill 1967; Mayhew 1851; Williams 1988). One such account notes:

But probably the biggest piece of territory in Fiddler's Green was that occupied by Sailor John's home-fromhome, the boarding-house. On every main street, up every back crack, alley and cul-de-sac, these sailor lodginghouses were to be found. Many of the more respectable ones would be run by ex-seamen--men too old for the arduous deep-sea life. A decent bunk, fair grub, a few drinks, and a ship when the money was gone was all that most sailing-ship Johns asked for, and the better-class boarding-housemaster provided just these things. Decent masters were to be found the world over, in Hamburg, 
Sydney, Amsterdam, Melbourne, Cape Town, and Rotterdam... (Hugill 1967:82).

A Norwegian maritime historian writing in the early part of the twentieth century describes sailors' taverns as:

rather simple boardinghouses for seamen. The chief, the boardinghouse master, provided the seamen living in his establishment with food, lodging and a considerable amount of drink. He also took it upon himself to make sure that his guests obtained berths on other ships and returned to the sea once again [my translation] (Eriksen 1968:27).

He notes however that:

In many instances, the boardinghouse was run purely to cheat the seamen. Keeping accounts of the seaman's debts to the boardinghouse master was a swindle and the seaman would often have to pay for things he had received as well as things he had not received. In the end, he was sent to see once more and the boardinghouse master could put most of the wages advanced to the seaman in his own pocket [my translation] (Eriksen 1968:28).

\section{The Janus Face of the Tavern}

Mixed assessments of taverns run throughout the literature. Sometimes, the same author could present opposing judgments. Melville, for example, describes in Moby-Dick a rather jolly tavern landlord of The Spouter-Inn, providing Ishmael and his fellow lodgers with sleeping space and substantial meals (1993:10-21). But, as early noted, elsewhere Melville places landlords first on his list of the "human rats" and "vermin" preying on sailors. Most commentaries on tavern life, however, are polarized into two camps. On the one side, taverns are portrayed as providers of a number of material and social services for sailors, while on the other, they are seen as places cheating and exploiting sailors in many ways. 
This latter view is dominant in descriptions of tavern proprietors and other staff operating during the eighteenth, nineteenth and early twentieth centuries at times of increased demand for shipboard labor. Accounts from that period focus particularly on tavern proprietors and staff engaged in "crimping" activities; i.e., recruiting and, in some instances, shanghaiing sailors.

One richly detailed study of a boardinghouse tavern on Montreal's waterfront describes its operations as an informal labour exchange (de Lottinville 1981/82). Sailors, however, were but a faction of the tavern's 200 lodgers. Moreover, this tavern deviated from the usual crimping practices of tavern keepers by recruiting workers primarily for shore work. As noted by the historian Conrad Dixon, accounts of crimping in tavern contexts tend to equate relationships between tavern keepers and seafarers to those of predators and victims. But this perspective he argued "ignores the reality that many merchant seamen voluntarily placed themselves in the hands of the crimps"(1984:49). In calling for a more balanced view of crimping, Dixon as well as his fellow historian Fingard $(1989,1982)$ suggest that sailors may have benefited from what appears on the surface to be devious practices by landlords for taking control over the money and labor of their lodgers.

This historical interpretation of the tavern, however, represents a minority viewpoint in a literature emphasizing the duplicity and greed of tavern keepers. C. Fox Smith provides a fairly representative account of this perspective in describing the reception accorded sailors preparing to leave their ships:

Before his ship had fairly docked a horde of boardinghouse keepers ... .were over her rail, insinuating themselves into the good graces of the seamen, plying them with rotgut liquor, and speedily gaining the reputation of being the best of good fellows and a real friend to sailormen. And off rolled poor Jack to his "'home from home" in the filthy purlieus of the Highway, there to remain half 
drunk until his pay was spent and he was well in the debt of his erstwhile hospitable host, who then sold him to an outward-bounder like so much cold mutton, and pocketed his advance, having made a great show of generosity by endowing his victim with a shoddy pretence of an "outfit." (1924:28).

Another commentary along similar lines describes the welcome provided to sailors entering new lodgings:

In the boarding-house Jack would be greeting effusively by the inmates: barmen (many of the houses had a bar), pimps, girls, and hangers-on, as well as resident seamen. Some had attendant girls, but most brought them in from outside bordels. (Hugill 1967:85)

Another historian, quoting from observations made by a Finnish pastor carrying out missionary work among seamen in London, writes:

In the vicinity of the Radcliffe Highway there are three lodging-houses run by Finns. All three sell alcoholic beverages, but only one is a public house. The Finnish flag, which waves above the door, gives the place an appealing look from the outside. But what is this external attractiveness compared to what goes on inside? Here the eye is entranced by beer and spirits and whatsoever a thirsty throat can desire--everything is to be had here, and in full measure. And amongst these beverages romps a gaggle of women, who have long since forgotten what feminine modesty is. We can well understand that there is no shortage of seamen in this public house (Kirby 1982:43) One sailor, interviewed in the 1850 s had this to say about life in sailors' taverns:

Men are encouraged to drunkenness and all kinds of debauchery ... [there are] lodging-houses who provided women who acted as wives (sometimes actually participating in marriage ceremonies) during Jack's 
stay ashore. Tales of drunken seamen being encouraged to stand treats, being short changed, and being robbed abounded, and there were extreme cases of kidnapping of seamen to supply them to unscrupulous captains, and even of seamen of Russian and Prussian ships being encouraged to desert through the inducement of better berths in British vessels....(1988:119-20)

The folklore of seafaring, too, provides a similar perspective of the treatment of sailors in such establishments. In the sea shanty "Get Up Jack, Sit Down John", the guile as well as the ale and stew (scouse) served to tavern lodgers is described with some cynicism:

When Jack's ashore he beats his way unto some boardinghouse.

He's welcomed in with port and gin likewise with beer and scouse.

He'll spend and spend and never offend'til he lies drunk on the ground.

But when the money's gone it's the same old song.

Get up Jack, John sit down.

In a recent occupational study of seafaring, its sociologist and former seaman author adds a newer note to the negative picture of taverns and their predatory proprietors dominating the literature:

the crimp would entice the ... seaman with the prospect of higher wages on another ship, liquor, women and other unaccustomed luxuries. He would then enter the crimp's boardinghouse, be relieved of what money he had [and] allowed to run up a debt... (Forsyth 1989:6)

Using a number of sources, one historian constructed a composite version of what typically happened to sailors in such taverns following his initial welcoming party involving "all the denizens of the boarding house including lodgers who 
were themselves givers of the feast some days before..."(Dixon 1984:53). Later, however, the sailor:

finds that he is relegated to a distant chair at mealtimes, has the smallest portion of food, and may be moved to a smaller room or told to share one with other men who have run out of money. There is a cold atmosphere,.... The crimp breaks the news that the money kept on his behalf has now all gone on his pleasures and maintenance, and the seaman asks the crimp to find him a ship. (Dixon 1984: 53).

A small number of commentators, rather then seeing taverns as sites for fleecing and exploiting sailors, have focused instead on the positive aspects of tavern life. These accounts tend to be more objective and less moralistic than those documenting the many evils alleged to permeate tavern life. One sailor-historian, for example, acknowledges the existence of taverns exploiting their lodgers but then goes on to note those establishments providing lodgers with a range of creature comforts:

A few of the boarding-houses had their rooms built in imitation of a ship's fo'c'sle, to make Jack feel at home. All the rooms were furnished with straw palliasses... a rough table, a few chairs and a scrap of carpet to complete Jack's "home-from-home." (Hugill 1967:85)

Another historian elaborating on this theme writes:

Men would return time and time again to the same boarding house which, although it may have been a mere sordid hovel, and run by a rapacious father or mother figure, still represented home (Dixon 1984:55).

One view of the tavern serving as a comfortable home for lodgers is found in a volume on maritime history in the form of a drawing showing the interior of a sailors' tavern in an unnamed European port of the early twentieth century. This shows a seated group of four lodgers relaxing while talking and drinking around a corner table. In another corner of the tavern, 
one lodger reclines on a bench while talking with another who is standing. Participating in their conversation is a third lodger who sits on an adjacent bench. Some of the lodgers wear work clothes, while others are clad in suits and vests. Behind them, drawings and paints of sailing ships decorate the tavern's walls (Brochmann 1916).

This picture of a home-like tavern atmosphere dovetails with a description of tavern accommodations in "Tomorrow," a short story by Eugene O'Neill. In it, he tells of lodging rather comfortably in one of the double rooms of a sailors' tavern having twin beds and a window overlooking the backyard (1917).

In a biography of O'Neill, the author described the proprietor of the tavern who provided O'Neill and others with lodging as extremely helpful and kind to sailors. The biographer found that the daily servings of soup and food on the tavern's free lunch table provided lodgers with "a feeling of last-ditch security" (Sheaffer 1968:192). As recalled by a ships' chandler who knew this tavern keeper for many years, he was:

generous to seamen down on their luck. He gave shelter to more than a few in his flophouse above the saloon... and, unlike the regular boarding masters, never squeezed them for blood money when they had landed a berth. (Sheaffer 1968:190)

One indication about the regard O'Neill held about tavern life is found in the recollections of his widow, who recalled that despite living in fine homes in France, California and the Atlantic seaboard, he was most fond of "his down and out period around the waterfront” (Sheaffer 1968:191). Given the many glimpses of tavern life emerging in O'Neill's dramas, it may be helpful to examine these in context of what is known of his experiences as both sailor and lodger. These will then be compared to the treatment of the tavern found in the writings of Henry Mayhew, another former sailor and pioneering social historical researcher. 
O’Neill and Mayhew: Social Historical and Dramatic Views of the Tavern

During 1911 and 1912 while O'Neill was not actively sailing as a deck seamen on several vessels in the Atlantic, he lodged at Jimmy the Priest's, a tavern located at 252 Fulton Street in lower Manhattan. This place had a saloon on its ground floor and sleeping accommodations spread out on its upper floors. Housed in an aged brick building adjacent to a ships' chandlery, the tavern bore no name. The only decoration on its front was a picture of a glass of beer accompanied by a sign reading "SCHOONER -5 ". For sailors and others lodging at the tavern at a cost of three dollars a month, the free-lunch spread and soup accompanying it provided a regular source of sustenance (Sheaffer 1968:188-208).

According to those who knew him, the tavern's keeper was "something of a Jekyll-Hyde mixture of offhand kindness and cynical toughness" (Sheaffer 1968:190). Known to his regulars as Jimmy the Priest, this man served as model for the tavern keeper, Johnny the Priest, in O'Neill's Anna Christie where he was described as follows:

With his pale, thin, clean-shaven face, mild blue eyes and white hair, a cassock would seem more suited to him than the aprons he wears. Neither his voice nor his general manner dispels this illusion which has made him a personage of the water front. They are soft and bland, but beneath all his mildness one senses the man behind the mask--cynical, callous, hard as nails. (1951:3 [vol III]) In The Iceman Cometh, O'Neill characterizes another tavern proprietor as:

one of those men everyone likes on sight, a softhearted slob, without malice, feeling superior to no one, a sinner among sinners, a born easy mark for every appeal (7:1957) This entirety of this drama takes place in a tavern and O'Neill acknowledged that it was heavily influenced by his experiences as a sailor between ships lodging in Jimmy the Priest's (Sheaffer 
1968:188-208). The play's action revolves around a group of lodgers huddling together for comfort and sustained by rounds of drinking and sharing their illusions about themselves, their lives and their futures. These men take refuge in the tavern seldom venturing outside its doors. They justify this by describing the dangers of the outside world: a society populated by cold, hypocritical and hostile people. Rejecting it as much as it rejects them, they find comfort in one another's company. In talking, drinking and sharing their "pipe dreams", these men (and a few women) form themselves into a small self-contained society threatened only when their illusions about themselves and their lives are challenged.

Less dramatic but detailed accounts of life ashore for sailors living in taverns and other accommodations are found in the reports of Henry Mayhew. Like O’Neill, Mayhew had worked as a seaman, sailing between England and India. Later, he became one of the founding editors of Punch and is today best known for his monumental London Labour and the London Poor (1861-1862). These four volumes documented conditions of life and work experienced by many groups in England previously invisible to reading audiences. In a co-authored assessment of his place in the development of social historical research, Edward P. Thompson praised Mayhew's sense for detail, while Eileen Yeo characterized his methods as a significant breakthrough in the development of social scientific research (1971).

A decade prior to the publication of these volumes, Mayhew wrote a series of articles, or letters about seamen he called them, for a London newspaper (1851). These writings are noteworthy in many respects. Firstly, he based his reports about sailors' life in taverns and elsewhere on his own observations as well as materials collected in interviews with sailors, boardinghouse masters and others providing housing for sailors ashore. Rather than representing these persons as was customarily done in the largely moralistic attacks against sailors' taverns, Mayhew allowed them to represent themselves. Secondly, Mayhew was one of the 
first commentators on tavern life to suggest connections between the workplace of the seaman afloat and his accommodations on land. As a result of his own seagoing experiences, Mayhew had a particularly keen understanding of how shipboard work impacted on the lives of seafarers and divided his account into two parts: the sailor afloat and the sailor ashore.

As historian David Williams put it in his detailed study of this groundbreaking research, Mayhew possessed an appreciation of: the unique position of the freshly discharged seaman compared with other workers--that of possessing relative wealth through the accumulation of months or years of wages, but probably lacking a home or family to go to and anxious for the creature comforts denied him during his time afloat. (1988:119)

By viewing the seaman's time ashore as a necessary respite and in acknowledging that the ship required its workers to forfeit much of their family and home life, Mayhew began to grasp what many other commentators had ignored: namely, the possibility that taverns provided lodging seamen with more than drink, food and beds. A third feature of his research reinforced this linkage. Unlike most writers of his day who championed charitable institutions for sailors as morally uplifting alternatives to the alleged dangers of the tavern, Mayhew was highly critical of them. In particular, he raised a number of objections to the way sailors were treated by the Sailors' Home, a charitable institution claiming to be established for the "protection" of seamen. This was a massive building providing lodging for sailors in 300 small sleeping rooms, or cabins, as they were called. In addition, this establishment included a classroom, library, a bible collection and banking facilities, decorated here and there with bible quotations. After observing the home and interviewing its inmates, Mayhew was highly critical of its policies and practices--especially the callous treatment given sailors too sick or otherwise unable to pay for their lodging. Mayhew also found that this charity charged more than taverns in providing lodgers with similar services. 
Most significantly, his research revealed that its agents, whose techniques of recruiting lodgers were no different than those of tavern crimps, engaged in a number of corrupt practices involving money advanced to sailors.

Mayhew then compared these findings to the interview and observational materials he collected about conditions for lodgers in taverns. Despite their poor reputation, he found that a number of taverns offered good accommodations for sailors. His research was evenhanded, and so after visiting what he termed the "better class of seamen's lodging houses," he directed his attention in the opposite direction. In the words of Williams, moving:

down the scale, Mayhew enquired into the worst class of boarding masters, or "crimps," an account which encompassed dubious houses kept by dockers or the "lower orders of Irish," and reported on even less savoury activities and establishments in "'Skinner's Bay," East Smithfield brothels, kidnapping houses in league with brokers' office, and so on (1988:119).

In assessing Mayhew's writings, Williams credits him for demonstrating the presence on the waterfront of more seemly taverns "where seamen appear to have gained a fairer treatment, less exploitation and better value for their money"(1988:120). According to another historical treatment of this period, the alternative for the sailor ashore outside sailors' taverns "was to lodge at one of the clinically clean, but cheerless, sailors' homes established by the 1850 act... (Dixon 1984:65).

\section{A Cultural Framing of the Sailors' Tavern}

One way for making sense of these disparate accounts is to apply a cultural frame to the recurring patterns of tavern life. This involves understanding that tavern regulars, like those groups everywhere, develop their own cultures as their members engage in face-to-face interaction over time. Viewed by outside observers, cultures typically present themselves as disparate and 
confusing entities. These become fewer the nearer observers come to the conditions of life impacting those sharing a culture. And if the observer joins these culture bearers and participates in their everyday activities, the symbolic system or culture they develop and share for dealing with forces impacting on their lives become meaningful and indeed reasonable. This is a prime lesson learned by anthropologists and other social scientists employing participant observational methods and one serving as a guide for the ethnographic fieldwork earlier carried out by this writer.

This yielded a picture of tavern culture reordering and making sense of a number of the conflicting descriptions of sailors' taverns found in the literature. When individual sailors lodge one or twice in a drinking establishment, it most likely is just a place to live ashore. But when a group of sailors keep returning to the same tavern for years, it become a an anchoring point in their social lives: a site where they develop and shape a symbolic system to deal with the conditions and contingencies influencing their lives. They shape this tavern culture and it, in turn, shapes them In analysing this culture at close hand, it appeared to be a system providing lodgers with continuity, permanence, and cohesion otherwise absent from or greatly lacking in their social environments at sea. The statement--real sailors have no friends-often uttered by seafarers captures many of these deficiencies. ${ }^{2}$ It can be understood as reflecting in a very direct manner sailors' experiences of working and living in a milieu of social flux and discontinuities.

These conditions are a consequence of the extremely high rate of turnover at sea. This means that individual sailors witness as well as join the stream of workers constantly arriving and departing from ships. This in turn greatly limits opportunities for seafarers to establish and maintain stable social relationships. As protection against the emotional costs of constantly severing social ties, sailors tend to develop diverse strategies for avoiding or minimizing affective relationships with their shipmates. By maintaining distance from and emotional investments in 
shipmates as friends, they thus insulate themselves from feelings of loss and sorrow occasioned when they as well as their shipmates inevitably depart from the vessels employing them.

In contrast, the tavern provides its sailor-lodgers with a much more permanent and durable social milieu. It resembles in some ways a landlocked vessel crewed over time by many of the same persons. Clearly, the most permanent actors in the social system of the tavern are its proprietor(s) and serving staff. Lodgers come and go, but bartenders, barmaids and tavern keepers remain as fixtures for years and, in some cases, decades. Although a tavern's regulars arrive and depart at irregular intervals, their limited numbers insure they can expect to be greeted by one or more familiar faces. Repeated experiences of this sort in combination with long-term contact with tavern staff provide lodgers with forms of social continuity, support and security unlike what they may experience at sea. This shared sense of community allows lodgers to invest in one another positive feelings they otherwise suppress when caught up in the constant flow of broken social ties at sea. Thus, the tavern serves as a haven of permanence and stability for those whose lives at sea are steadily marked by disruptions, discontinuities and flux in social relations.

The security that lodgers seem to find in the tavern may explain why so few of them venture far from it during their time ashore. It is not uncommon to meet lodgers of many years standing ignorant of the streets and stores in the tavern's immediate neighbourhood. In the tavern, they often tend bar and wait on tables as well as cook for themselves. Since lodgers often come to the tavern from vessels where they may have worked hundreds of days at a stretch, these unpaid tasks may help mitigate the kind of uneasiness accompanying sudden and unaccustomed inactivity often experienced by sailors as well as newly pensioned workers.

These small jobs represent but one of several forms of continuity between sea and land found in tavern life. Perhaps the most important of these carryovers is the ship-like atmosphere created by a number of the tavern's physical and structural traits. Lodgers, 
like newly released prisoners, mental patients and others leaving similar institutions, may experience fears and anxieties of fitting into patterns of non-institutional life. ${ }^{3}$ Yet, while other ex-inmates enter unfamiliar territories, lodgers enter a setting where all aspects of life are carried out in a tightly enclosed space in the company of others under one roof. Despite the similarities of tavern and shipboard life, lodgers seldom acknowledge these. On the contrary, a prominent conversational theme for lodgers takes up the many contrasts between the freedom of tavern life and life spent as "voluntary prisoners" aboard ships at sea.

Conversations about this and a handful of other topics constitute the main activity of tavern life. From morning to late at night, tavern regulars share tables talking and drinking. Though they may consume considerable amounts of beer and spirits during the course of a day, it is unusual to see any lodgers drinking themselves into a stupor. The speech of some may become slurred and their movements clumsy, but arguments and angry outbursts are extremely rare. More common, however, are tearful episodes when lodgers relate stories heavy with feelings about marital break-ups and family troubles. Since problems of this sort are a common experience of most lodgers, they invariably meet the sad tale told by one with sympathy and consolation. Although they frequently tease one another about their respective shipboard occupations and nationalities, this is mildly done and without noticeable malice.

Talk flows continually in the tavern and is characterized by balanced turn-takings mirroring the lodgers' customary practice of buying rounds of drinks for one another. Though a newly discharged tavern regular may dominate table talk in bringing in information from the world outside the tavern, once these topics are exhausted conversations return to a handful of usual topics. One involves the narratives they tell of their lives at sea and in ports round the world. Another is their shared disdain for crew and officers who always sail--sometimes for years at a stretch--aboard vessels owned by the same shipping company. In 
swapping tales about "company sailors" as others institutionalized and subservient to ship owners, lodgers construct a picture of themselves as free and independent "real" sailors.

One set of themes is recurrent and revolves around their view of the tavern as a community of its own. They celebrate the many qualities existing among themselves and contrast these to those found elsewhere in the world. Lodgers elaborate endlessly about forces of greed, exploitation and hypocrisy they have observed and experienced as highly mobile eyewitnesses to world events, global commerce and politics. In their table talks, they make use of their shared wealth of knowledge in making unfavorable judgments of governments, corporations, political leaders, bureaucrats, police and a host of others. In continually counterpoising themselves against the many targets of their contempt, lodgers talk in to existence an image of the tavern as a solitary haven providing them with mutual caring and solidarity they see so little of in the outside world.

One topic, however, is almost never taken up even though it makes possible among other things the drinking accompanying these conversations. Tavern regulars buying rounds of drinks for one another do not pay for them in cash. Their drinking as well as lodging expenses during the entire period of their stay is made possible by the credit extended them by the tavern owner. Unlike other debtor-creditor relationships, those of the tavern keeper and lodgers are not formalized in written contracts. They share instead an understanding that the owner keeps running accounts of lodgers' debts incurred during their stays. These amounts are then repaid when lodgers return to the tavern after their next spells of work at sea. This means that the basis for the relationship between owners and lodgers is one of mutual trust and dependence; owners trust and depend upon lodgers to repay their debts upon their next discharge while lodgers depend and trust owners to give them credit and keep accurate accounts of their debts. Yet, perhaps the most significant of all that is not said about these understandings of their mutual obligations is that owners need to 
have lodgers who do not overstay their welcomes. In order for the tavern to be viable, lodgers are required to terminate their spells ashore and return to work. If they remained too long in the tavern, the owner eventually run out of funds used for purchasing the drink and food daily consumed by lodgers as well as fall behind in rent and mortgage payments for the tavern. Thus the tavern's continued existence depends upon lodgers never overstaying their spells ashore, but this vital facet of the debtor-creditor relationship is forever absent from tavern conversations.

It is, however, ritually confirmed in some ways by the celebrations marking the return to the tavern of former lodgers newly discharged from ships. Their arrivals are marked by "payoff" parties where drink and food are provided freely for all-sometimes including those who happen into the tavern. At this time, returning lodgers pay for the cost of these festivities and repay their debts from previous stays from the cache of money they have accumulated from their wages at sea.

These parties thus ritualise the fulfilment of the debtor-creditor relationships in the tavern as well as the return of tavern regulars, often accompanied by shipmates seeking lodgings. These celebrations break the everyday routine of tavern life and often assume legendary proportions in the folklore of the tavern. For returnees, these parties mark genuine homecomings: they call the tavern home and often travel great distances to reach it from ports of their discharge.

Though the tavern is largely a male domain, barmaids as well as wives and partners of proprietors may also play an important role in the everyday lives of lodgers. While bartending and waiting on tables, these women tend to spend much of their time talking and drinking with lodgers and sailors visiting the tavern as customers. In so doing, they do not hide the fact that part or all of their wages depend upon a percentage of the drinks they and their drinking partners consume. Lodgers view this practice as a normal part of women's work in the tavern. It is something sailors meet in drinking establishments around the world and it has little effect 
on their interactions with these women. Their verbal exchanges tend to resemble for the most part the bantering and confiding relationships characteristic of old friends and family members. For some of the tavern's women, such as those who have lost or abandoned their own children, their relationships with lodgers may have something to do with their own needs. In keeping with the mother-son and brother-sister family-like character of many of their interactions, only rarely do romantic relationships develop between the tavern's women and its lodgers. Unlike women providing paid sexual services that sailors are accustomed to meeting in ports, the tavern's women lodgers give lodgers chances to engage in interactions meaningful to their social, rather than sexual, identities as men. Shipboard life traditionally has meant having no or little contact with women and for men coming ashore after long periods at sea, gaining practice in conversing normally with women may help allay their fears about fitting into normal patterns of life on land.

\section{Tavern Culture: Oppositional or Illusionary}

In recent years, a number of richly detailed and documented historical studies of seafaring have added to our understanding of the sailor's lot (Creighton \& Norling 1996; Linebaugh \& Rediker 2000; Rediker 1987). We now know a great deal about the cultural systems of dealing with and interpreting the world shared by sailors irrespective of their ethnic and national backgrounds. Owing to the nature of global commerce, ships always have been multicultural and international workplaces. Consequently their crews have had to develop cultural systems for transcending national and ethnic boundaries.

The character of cultures borne by seafarers has yet to be fully explored, but recent historical accounts have linked such systems to the role of sailors as a maritime working class shaped by the forces of capitalism while at the same time resisting them. Accordingly, there has been a tendency to view the places where 
sailors gathered, notably the ship, as sites of solidarity, resistance and rebellion. If framings of what Rediker, Linebaugh and others refer to as the "oppositional culture" of sailors at sea is a correct one, we should expect to find it existing as well among sailors ashore in taverns.

Most certainly, it is possible to see certain aspects of tavern life as reactions to and opposition against structures and dynamics of work and life at sea. Shipboard life, for example, rules out much of normal family life. Traditionally, sailors must be away from their families to provide them with income. And so, when a sailor returns home, the family's income ceases and thus creates a number of hardships. An added problem for returning sailors is that they frequently experience themselves as strangers in their own homes because families have restructured themselves during their absence. Many sailors report tiring of dealing with the constant problems of homecomings and elect not to return home. Consequently, a history of marital break-ups and eroded ties to children is one shared by many tavern lodgers.

The family, for most of us, is the site of our most intense social and emotional relationships. It is the primary group we first encounter and our identities are much dependent on the face-toface relationships we experience in the family. The atmosphere of this primary group is one we later seek to replicate later in establishing our own families and best friends. In our primary groups, we are disposed to disclose much of our selves in the company of supportive and non-judgmental others.

For sailors unable to sustain primary relationships in their own families and prevented from establishing such relationships by high turnover at sea, the primary group of tavern regulars is perhaps the next best thing. Indeed, the tolerance they exhibit toward one another and their strategies for avoiding conflicts resemble those characteristic of more other better known primary groups. Moreover, the family-like relationships developed between lodgers and women of the tavern provide another indication of how tavern society functions as an alternative to the 
family life denied lodgers by their seafaring work. In this respect, tavern culture may be seen as developing in opposition to the social consequences of economic forces impacting on the lives of sailors.

Students of prisons, mental hospitals, and similar institutions housing persons cut off from the wider society have identified processes whereby long-term inmates become de-socialized or disculturated (e.g., Goffman, 1961; Sommer, 1959). This term applies to those whose experiences of long institutionalisation have made them incapable of managing their lives outside the institutions. These individuals have forgotten, often through prolonged disuse, the store of recipes for action and reaction guiding the behavior of members of the wider society. In a number of ways, the tavern works to mitigate some of these problems. Like halfway house programs for newly released convicts and former mental patients, the tavern may be a hybrid: it is neither a total institution though it has many of the characteristics of a vessel at sea, nor is it the wider society even though elements of that society make their presence felt in the tavern. Its lodgers celebrate their liberation from the relentless work discipline of the ship, but choose to work at unpaid jobs in a remarkably similar isolated and closed social system. In this respect, tavern culture seems not to play an oppositional role, but rather one of extending the institutional context dominating so many other areas of lodgers' lives. ${ }^{4}$

Nonetheless, the tavern is still less ship-like than many of the homes, hotels and hostels established by various organizations for sailors ashore. With their communal cafeterias, scores of identical sleeping rooms, sparse furnishings, minimalist interiors, and formally administrated routines for eating, sleeping and other activities, these establishments recreate on land many of the central elements of shipboard life sailors wish to escape from when going ashore. The formalized control these places exert over the lives of their residents and their ties to shipping, governmental and religious interests make them poor soil for political and labor 
organizing. According to one sailor, who was a labor organizer and official in the Communist International, Moscow and Hamburg in 1924 decreed that institutions of this sort:

had to be wrecked and rooted out of existence. The war against them was waged for many years, and reached its violent climax in the early thirties when sailors' homes, included the largest of them all, in New York, became the scenes of riots and raids by wrecking squads under communist control (Valtin 1941:110).

Though sailors' homes and similar establishments long have presented themselves as alternatives to sailors' taverns, this opposition does not necessarily mean that the latter served as sites for political agitation and labor organization. While many drinking establishments share a history of resistance (e.g., Palmer 2000), it is difficult to envisage such a clear-cut role for the sailors' tavern. Instead it seems more likely that the tavern, rather than being a place for collective struggle against oppression, functions more as a free space for lodgers escaping for a time the conditions of the seagoing factories where they are required to sell their labor.

Yet, their freedom celebrated in many ways in tavern culture is often illusionary. Lodgers leave ships to spend time ashore to gain respites from the restrictions and discipline of shipboard work. But in moving to the tavern, they may be exchanging one large total institution for a smaller one. They vigorously proclaim, however, that tavern life provides what life at sea denies them. This is one of the main illusions of tavern culture.

Another significant illusion involves the worldview sustained by tavern culture. Lodgers devote much time and energy to describing with great cynicism the world outside the tavern. They find it populated by "others" totally unlike themselves whose lives are steered by greed, duplicity and strivings to profit on the misery and misfortune of others. Lodgers often point to the greedy yet miserly ship owners profiting on their labour as archetypical of the society lying beyond the tavern's doorway. 
Yet, in extolling the differences between that world and the tavern, they seem to blind themselves to the tavern keeper profiting from them in a number of ways. They accept without question the accuracy of their lodging and bar tabs and pay without protesting the amounts demanded of them by the tavern owner. More importantly, they never confront openly the fact that the owner's livelihood requires to have them out of the tavern and back to sea again--not at all unlike former spouses and partners berated for their greed in the tales told again and again at tavern tables

For lodgers to raise this and related issues of their relationship to the tavern keeper would be tantamount to treason in the context of tavern culture. The taboos attached to talking about tavern keepers depending on lodgers returning to the sea for their financial livelihoods corresponds to lodgers' needs for the credit making possible their membership in the tavern community. In order to hold on to their place in this community and thereby sustain the small store of primary relationships possible in their lives, lodgers harbour illusions about the nature of their relationship to the tavern keeper. As The Iceman Cometh demonstrated so dramatically in another tavern community, challenging and demolishing illusions results in the destruction of a life-sustaining system. In this sense, tavern culture is no different than any other culture since all are built up of illusions about the world maintained by their bearers. ${ }^{5}$ Like cultures everywhere possessing illusionary elements providing their bearers with security, sustenance and other benefits, the culture of the tavern seems to furnish its seafaring lodgers with comfort and support in an otherwise alienating occupation career in a world often manifesting itself in the form of a cold, calculating and heartless place.

Oslo University College, Norway Michael.Seltzer@oks.hio.no 


\section{References AND Notes}

Aubert, V. The Hidden Society (Totowa: Bedminster Press, 1966).

Aubert, V. and Arner, O."On the Social Structure of a Ship." Acta Sociologica 3 (1958-1959), 200-219.

Brochmann, D. Opsang fra seilskibstiden. Kristiana, 1916.

Bruijn, J. “Seamen in Dutch Ports, c.1700-c.1914.” Mariner's Mirror 64 (1979), 331.

Creighton, M. and Norling, L., eds. Iron Men, Wooden Women: Gender and Seafaring in the Atlantic World, 1700-1920. Baltimore: Johns Hopkins University Press, 1996.

Dana, R.H. Two Years Before the Mast. 1840; New York: Signet Books, 1958.

de Lottinville "Joe Beef of Montreal: Working Class Culture and the Tavern, 1869-1889." Labour/LeTravail 8/9 (1981-1982), 9-40.

Dixon, C. "The Rise and Fall of the Crimp, 1840-1914, in Stephen Fisher, ed., British Shipping and Seamen, 1650-1960. Exeter: University of Exeter Press, 1984.

Earle, P. Sailors: English Merchant Seamen 1650-1775. London: Metheun, 1988.

Eriksen, E. Vår gamle sjøfartskultur. Oslo, 1968.

Fingard, J. The Dark Side of Life in Victorian Halifax. Porters Lake: Pottersfield Press, 1989.

Fingard, J. Jack in Port: Sailortowns of Eastern Canada. Toronto: University of Toronto Press, 1982.

Fisher, S. Lisbon as a Port Town, the British Seaman and Other Maritime Themes. Exeter: Exeter University Publications, 1988.

Fisher, S. British Shipping and Seamen, 1650-1960. Exeter: University of Exeter Press, 1984. 
Forsyth, C. The American Merchant Seaman and His Industry: Struggle and Stigma. New York: Taylor and Francis, 1989.

Fricke, P.H. The Social Structure of Crews of British Dry Cargo Merchant Ships: A Study of the Organization and Environment of an Occupation. Cardiff: University of Wales Institute of Science and Technology, 1974.

Fricke, P.H. Seafarer and Community: Towards a Social Understanding of Seafaring. London: Croom-Helm, 1973.

Goffman, E. Asylums: Essays on the Social Situation of Mental Patients and Other Inmates. Garden City: Anchor Books, 1961.

Guthke, K. Traven: The Life Behind The Legends. Brooklyn: Lawrence Hill Books, 1987.

Healy, J. Fo'c's'le and Glory-Hole: A Study of the Merchant Seaman and his Occupation. New York: Merchant Marine Publishers Association, 1936.

Hughill, S. Sailortown. London: Routledge, 1967.

Kirby, D. “One hundred years of the Finnish Seamen's Church in London.” In 100 Vuotta, 100 Years of the Finnish Seamen's Church in London. Kajaani, Finland: Kainuun Sanomain Kirjapaino Oy, 1982.

Linebaugh, P. and Rediker, M. The Many-Headed Hydra: The Hidden History of the Revolutionary Atlantic. London: Verso, 2000.

Mayhew, H. London Labour and the London Poor. London: Griffin, Bohn and Company, 1861-1862.

Mayhew, H. Letters in the Morning Chronicle: 19 October 1849 - 12 December 1850. 1851.

Melville, H. Moby-Dick. Ware: Wordsworth Press, 1993.

Melville, H. Billy Budd and Other Tales. New York: New American Library, 1961.

Melville, H. Romances of Herman Melville: Typee, Omoo, Mardi, Moby-Dick, White-jacket, Israel Potter, Redburn. New York: Pickwick Publishers, 1928. 
Moreby, D. The Human Element in Shipping. Colchester: Seatrade Publications, 1975.

Nolan, B. “A Possible Perspective on Deprivation.” In P. Fricke, ed., Seafarer and Community: Towards a Social Understanding of Seafaring. London:

Croom-Helm, 1973.

O’Neill, E. The Iceman Cometh. New York: Vintage Books, 1957.

O'Neill, E. Bound East from Cardiff: The Plays of Eugene O'Neill, Volume 3. New York: Random House, 1951.

O’Neill, E. Anna Christie: The Plays of Eugene O'Neill, Volume 3. New York: Random House, 1951.

O’Neill, E. “Tomorrow,” Seven Arts, June Issue, 1917.

Palmer. B.D. Cultures of Darkness: Night Travels in the Histories of Transgression: From Medieval to Modern. New York: Monthly Review Press, 2000.

Palmer, S. "Seamen Ashore in Late Nineteenth-Century London: Protection from the Crimps." In P. Adam, ed., Seamen in Society, Proceedings of the International Commission for Maritime History. Bucharest, 1980.

Rawson, G. Sea Prelude. London: Blackwood, 1958.

Rediker. Between the Devil and the Deep Blue Sea: Merchant Seamen, Pirates, and the Anglo-American Maritime World, 1700-1750. Cambridge: Cambridge University Press, 1987.

Committee of Enquiry into Shipping, Rochdale Report. Cmnd. 4337. London: Her Majesty's Stationary Office, 1970.

Seltzer, M. "Beyond the Total Institution: An Ethnographic Report." Lambda Alpha Journal of Man 5:2 (1973), 75-89.

Seltzer, M. “The First and Last: A Study of Seamen Ashore.” Ph.D. dissertation, Department of Cultural Anthropology, Washington University, St. Louis, 1971.

Sheaffer, L. O’Neill: Son and Playwright. New York: Paragon House, 1968. 
Smith, C.F. Sailortown Days. London: Metheun, 1924.

Sommer, R. "Patients Who Grow Old in a Mental Hospital." Geriatrics 14 (1959), 586-587.

Thompson, E.P. and Yeo, E. The Unknown Mayhew. London: Penguin Books, 1971.

Traven, B. The Death Ship. New York: Alfred Knopf, 1934.

Williams, D. "Henry Mayhew and the British Seaman." In S. Fisher, ed., Lisbon as a Port Town, the British Seaman and Other Maritime Themes. Exeter: Exeter University Publications, 1988.

Valtin, J. Into The Night. London: William Heinemann, 1941.

Zurcher, L. "The Sailor Aboard Ship: A Study of Role Behavior in Total Institutions." Social Forces 43 (1965), 389-400.

1. These figures were provided this writer in the course of interviews with officials of the Danish Seafarers' Union in 1969. These calculations were corroborated by a non-representative sample of retired sailors as well as those nearing retirement also interviewed at that time.

2. Fricke reported sailors on British vessels frequently described their lack of social ties with the declaration: "I have no friends at sea: only Board of Trade acquaintances." (1973:5). Sociologist Helen Gouldner pointed out to this writer that a similar sentiments were common among highly mobile corporate wives she studied.

3. One study in 1970, the so-called Rochdale Report commissioned by the Committee Into Inquiry about Shipping of Great Britain, found a great many sailors reporting difficulties in "getting on" with people ashore. More than a third of the deck officers polled reported these kinds of problems.

4. Erving Goffman suggested to this writer that the tavern may represent a "tertiary adjustment" of inmates to the impact of total institutions. As well documented, drinking is a well known "removal activity" serving as a secondary adjustment to time and space constraints of prisons, military enclaves and most certainly ships. 
5. Even though cultural anthropologists often regard illusions as part of the belief systems found in all cultures, their role in these systems has received little detailed attention. Three noteworthy exceptions to this general neglect are represented by Weston La Barre's The Human Animal (1954) and Jules Henry's Culture Against Man (1963) and his later Pathways to Madness (1971). 